\title{
Chapter 7 \\ Managing Irregularity Through the Provision of Social Assistance
}

Policies and measures of social assistance and protection represent the core and ultimate safety net of the welfare state. Their aim is to reduce the social and economic vulnerability of poor or otherwise marginalised members of society by mitigating the risks associated with old age, illness or disability, as well as the loss of employment or other sources of income. Compared to the provision of and access to public healthcare and education, these targeted provisions arguably constitute a more explicit link between the state and a particular individual or household, since they often involve a direct transfer of public funds. Like other forms of public welfare, social protection systems are thereby based on the contributions - either employment-related or through general taxes - of potential beneficiaries, and thus hinge on a sense of trust and solidarity among all members of the 'community' (Banting, 2000; Alesina \& Glaeser, 2004). Following Thomas H. Marshall's (1950) classic conceptualisation of national citizenship as the successive conferral of civic, political and only then also social rights, Esping-Andersen (1990, p. 21) emphasised that "social citizenship constitutes the core idea of a welfare state".

Not only but particularly in advanced European welfare states, immigration has thus instinctively been perceived and treated as a potential threat to existing welfare arrangements, due to an increased competition of 'outsiders' for employment, public services and other resources (Borjas, 1999; Banting, 2000; Sainsbury, 2012). Quantitative analyses of opinion data suggest an inverse relationship between the inflow of newcomers - particularly if they are relatively low-skilled or poorly integrated into the labour market - and the level of support among 'native' populations for policies aiming at redistribution and social protection (Burgoon, 2014; Gaston, 2015). It has also been argued that "a political backlash against immigration and multiculturalism might help fuel a more comprehensive neo-liberal attack on the welfare state" (Banting, 2000, p. 22). Notably, the growing antiimmigrant rhetoric - traditionally associated with right-wing political parties - has 
indeed become part and parcel of how many governments are justifying welfare cuts that ultimately affect not just immigrants but also the 'native' poor. The same argument has also been turned on its head by studies suggesting that strong and inclusive welfare policies can also reduce popular hostility towards immigrants by decreasing their (visible) marginalisation and thus stigmatisation (PICUM, 2015) and lowering overall social inequality as well as the general risk of poverty (Artiles $\&$ Meardi, 2014). Banting (2000) therefore suggested that expansive welfare states based on (near-)universal social insurance systems are better suited to guard against anti-immigrant backlashes than slim welfare states, which are generally more prone to welfare chauvinism.

Openness for immigration ultimately involves the extension of social rights to foreign residents (Soysal, 1994; Ruhs, 2008) and their more or less equal representation in public and political discourse (Papadopoulos et al., 2008). From a strictly economic perspective, Martin Ruhs and Philip Martin (2008) posit an obvious trade-off between the overall number of immigrants allowed to enter and stay in a given host country and the social and economic rights afforded to them. In practice, and in order for immigration to be perceived as compatible with relatively extensive national welfare provisions, any level of openness must be mediated through ever more complex and stratified systems of immigration statuses and correspondingly differentiated rights (Morris, 2002). Irregular migrants' position at the very bottom of this hierarchy, and their explicit lack of formal membership further exacerbate the underlying frictions and make their inclusion a particularly contested matter. It has also been noted, however, that "the denial of the most basic social rights could create more economic costs than benefits for the existing population" (Ruhs, 2008, p. 420). This is obviously true for any category of residents and irrespective of the il/legality of their presence (PICUM, 2015), and can thus justify universal access to not only (primary) healthcare and (compulsory) education, but also basic social assistance and protection measures. In this chapter I therefore look at how migrant irregularity and its control interact with the various mechanisms of inclusion and exclusion that underpin the local provision of social assistance and protection measures in London and Barcelona. As in previous chapters I thereby focus on the perspective of welfare bureaucracies, which have long been attributed a decisive role in (re)negotiating immigrants' social rights and access to such services (Guiraudon, 2000; van der Leun, 2003, 2006). It is the third area of public service provision where individual street-level bureaucrats have to manage certain contradictory logics and obligations following from their own professional responsibilities on one hand, and immigration law on the other (Furman et al., 2012; Cuadra \& Staaf, 2014; Price \& Spencer, 2015). 


\subsection{Public Support for Non-members: Ambivalent Legal-Political Contexts for the Provision of Social Assistance and Protection to Irregular Migrants}

While the provision of public assistance primarily aims to achieve social inclusion and thereby preserve the overall cohesion of society, it always also entails a certain element of exclusion, since not every claimant will meet the legal and moralpolitical criteria of eligibility and deservingness (Hemerijck et al., 2013). Unless it is understood as a truly universal right, access to social assistance and protection is granted or denied either on the basis of need (such as absolute or relative poverty or evidence of destitution), previous contributions (in the form of taxes or social insurance payments) or membership. Possible loci of control and regulation of access by non-members are either the territorial border of the nation state or the internal boundaries of its welfare system or formal labour market. The negative consequences of welfare exclusion as well as the immediate costs of providing such services, however, are also felt at the local level (Price \& Spencer, 2014). Both in Britain and Spain this is partly because the gradual decentralisation of competences and responsibilities in this realm of service provision has not been matched by a corresponding redistribution of public funds. In Spain, the quite substantial shift of powers (starting in the 1980s) from central to both regional and municipal governments has resulted in a rather fragmented system of cash benefits and social care services delivered at various administrative levels (Moreno \& Bruquetas, 2011; Rodríguez-Cabrero, 2011). Not only for (irregular) migrants - whose eligibility often precisely depends on which level of the administration finances a particular service - it is difficult to discern the various components (and corresponding competences) of this system. The following account of the director of a migrant community organisation in Barcelona reflects this complexity:

There are support measures ['ayudas'] from City Hall that are different from those of the Generalitat [the Catalan government]; [whereas] the minimum income support [RMI] doesn't really come from the Generalitat but from [the central government]. What happens is that the Generalitat de Catalunya administers the RMI, but all the other benefits, like let's say the grant for the children to eat at school, the help to pay the rent, to pay the electricity... all these are local measures that the city can decide to whom they are given and to whom not (bcnA01).

While the influence of local government, and thus also the variation between different municipalities in this regard, has increased during the years of fiscal consolidation, both the central government and most Autonomous Communities have rigorously reduced their expenditure in all areas of social policy (Moreno, 2007; Moreno \& Bruquetas, 2011; Rodríguez-Cabrero et al., 2015). Empirical research has shown that irregular migrants have been particularly affected by the economic downturn, which coincided with various government proposals to further restrict their access to basic services and employment (Manzanedo \& Fabre, 2009).

In Britain, the devolution of competences in the field of social policy has been less far-reaching but like in Spain it was accompanied by significant cuts to central 
government funding for local authorities (LAs) to provide social services to their residents (Hastings et al., 2013). Almost all of the local administrators and practitioners I interviewed in London mentioned insufficient resources as the most significant barrier to an effective provision of social care and support services. As the immigration advisor of a local Citizens Advice Bureau emphasised, this is not only an issue in relation to the specific needs of irregular residents but also other parts of the population and areas of provision:

There is this tension between the central government and the LA as to who is responsible for these very vulnerable people. And that plays out aside from immigration, isn't it? I mean that's also with the cuts; the government is cutting LAs' budgets and is expecting them to do more and better work (lonA19).

Facing increasing pressure from LAs as well as civil society, the central government re-introduced a specific funding stream - previously called 'Migration Impacts Fund' (2009-2010) - that should help LAs to deal with "the impacts of immigration on local communities" and on locally provided services in particular. Since 2016, the 'Controlling Migration Fund' essentially aims to achieve the same goal, but mainly by reducing the number of unlawful residents, which in turn requires a closer cooperation between LAs and the UK Home Office in order to implement additional measures of immigration enforcement (Department for Communities and Local Government, 2016). At the centre of these developments are the legitimate claims of increasing numbers of immigrant families - in mostly irregular but also certain regular situations - who according to immigration rules have no recourse to public funds, but still a fundamental right to receive support from their local Council if otherwise they would become destitute and that would constitute a breach of a child's human rights (Price \& Spencer, 2015).

At the same time, and in both countries under study, social services are increasingly expected to fulfil much of their function by '(re-)activating' people for gainful employment, i.e., channelling them (back) into the formal labour market. While certainly not a new trend (nor specifically related to the management of migration), it underpins another important mechanism of excluding irregular residents from longer-term social assistance. Since at least the beginning of the 1990s, British welfare policy has been characterised by a strong reliance on employment and 'employability' as the central elements of so-called 'workfare' and later 'welfare-to-work' approaches to reducing poverty and social exclusion (Hemerijck et al., 2013). The same trend has also, although more recently, become apparent in Spain, where "activation has progressively become a key element in the new social assistance schemes, as well as in the reforms introduced to unemployment programs since the early 2000s" (Rodríguez-Cabrero et al., 2015, p. 14). State support is thereby increasingly made contingent on clients' active and often full-time job seeking, as well as their participation in official training and job qualification measures. The following account of a social worker I interviewed in Barcelona shows that this logic makes it more difficult to 'successfully' do social work with a client who is unlikely to eventually enter the formal labour market, whether because there are generally no jobs available or because that person has no permission to work: 
[Irregular migrants] are usually more linked to Caritas than to social services because Caritas can provide this more assistential support. [...] But we are in another logic now, more [about] promotion of the person, which is something you cannot do with these people because the promotion happens through work. [...] And if there are no jobs, what the hell are we going to do? Obviously, the irregular person is the most brutal case, the clearest, most paradigmatic, but this is also happening with people who are Spanish or are regular immigrants: What do we do if there is no work? (bcnA21)

Like in the areas of healthcare and education, the inclusion of irregular residents in the local provision of social assistance and protection requires the reconciliation of contradictory legal frameworks and institutional logics, which in turn can lead to rather unexpected outcomes and alliances, as I will show in the remainder of this chapter.

\subsection{Legal Frameworks, Formal Entitlements and Practical Barriers for Irregular Migrants' Access to Social Assistance Provided in London and Barcelona}

In outlining the formal frameworks and in order to highlight the various contradictions and practical barriers that arise in the course of their implementation, I differentiate - as in the previous chapters - between the provision of basic and more substantial or longer-term support.

\subsubsection{Irregular Migrants’Access to Basic Support}

Basic forms of social assistance and protection aim to alleviate the most immediate and pressing symptoms of destitution, such as street-homelessness or the inability to cover alimentary or other essential needs. They address temporary hardship through emergency social care services including night shelters, food banks or soup kitchens, but also individual counselling and street work. Such measures do not involve substantial cash transfers and are often accessible to any person who exhibits a specific need. Both in the UK and Spain, the principal responsibility for providing these services to particularly vulnerable individuals and families lies with the LA, i.e., the city or Borough where they officially reside. That said, also charities and church organisations have traditionally played an important role in this regard (and in both national contexts), by providing additional services to those who have 'fallen through the cracks'. A representative of Caritas who I interviewed in Barcelona emphasised that it is not only but especially in the context of migrant irregularity that the Third Sector has to make up for generally insufficient public provisions:

In relation to irregular immigration, it's just... they [public services] don't do anything. It's like, I don't know, sometimes I wonder: if in Spain there were no private entities... who 
would take care of all this population? Of 20,000 [clients in Barcelona] we have 3,600 [in an irregular situation]. Where would these people be? Some of them we provide with housing, many receive financial aid, we help them with their regularisation, and we have psychologists who support them... because otherwise, where would all these people be? I believe that the Third Sector in Spain is what [prevents] a time bomb, mainly in relation to the [irregular] migrant population, but also in general (bcnA03).

At the national level, while the relative share of social services and benefits addressing basic needs has increased (from 33\% in 2007 to $50 \%$ in 2011), local governments' overall social expenditure has decreased by almost $20 \%$ between 2010 and 2013 (Rodríguez-Cabrero et al., 2015, p. 16/7). Within this context, and in order to counter social tensions and the growing risk of social exclusion and disintegration, the city government of Barcelona has taken steps to compensate for the lack of universality that increasingly characterises central government policy in this field. A universalistic approach is particularly crucial in the context of sustained immigration, as a former City Councillor for social welfare wrote in an official publication:

[T]he universal nature of social services is absolutely fundamental in the medium and long term because it is necessary that social services can continue to manage in a sustained way the tensions generated by the pressure that newcomers [put on our] care services. As long as this universalisation does not occur [at the national level], the City Council has chosen to strengthen its network of primary social care, so that the criterion for attending the users [can] be based on their needs and not on their origin (Gomà, 2006, p. 117, own translation).

While in Spain the provision of primary social care services is generally a municipal competence, Barcelona occupies an exceptional position also within Catalonia in that it also administers specialised social care services. The costs of these provisions should - according to official agreements - be equally shared between the state, the Catalan government and the municipality, but in the case of Barcelona around $80 \%$ of the costs are effectively covered by the city alone, a fact that the local government has referred to as "the historical deficit in financing municipal responsibilities for policies of inclusion" (Ajuntament de Barcelona, 2005 , p. 61/2, own translation).

For migrants who irregularly reside in Barcelona, this means that at least in principle, they can access those elements of social service provision that directly depend on the municipality, as the director of the city's Department for Immigration and Interculturality assured me:

If you are irregular you cannot work, or at least [not] legally, and [...] you cannot opt for any of the regular economic benefits like the RMI... But then on the other hand, what we do on the part of the Municipality is... well, anything that we are not forbidden [to provide] by law, we offer also to them. So, a person who has these needs and is irregular can still go to social services and generally, if s/he really needs it, will receive help. If it's necessary for food and other basic needs... for these basic things not only does [the law] not prohibit this, but our Social Services Law says very clearly that everyone has to be attended, regardless of their legal status (benA18).

The legal basis for this, however, is not only laid out by municipal law but also Spanish immigration law, which stipulates that all "foreigners, regardless of their 
administrative status, are entitled to basic social services and benefits". ${ }^{1}$ For the director of one of the city's 40 social service centres (SSC) it is obvious that what justifies this comparatively open access for irregular migrants is the immanent link between an individual's access to such services and his or her social inclusion:

Of course, all financial aid that [comes] from the City Council [...] is geared towards inclusion. So, it addresses situations in which a family or an individual needs support for... well, to be able to function. It aims at [their] social inclusion. Obviously, these aids always have to be linked to a basic need, or more or less basic, such as the Solidarity Card ['Tarjeta Solidaria'], which is for food, so very basic; but there could also be some help to buy new glasses, for example (bcnA20).

Like with other local services, what ultimately gives access to such support is the claimant's official - even though not necessarily legal-residence within the municipality. As an NGO representative who also works as intercultural mediator within the public health and social care system explained to me, however, the lack of specific documentation certifying local residence often constitutes a practical barrier:

In the case of social services, whether or not someone has access to a benefit - whatever type of benefit - is strictly conditional on [local] registration. It's not enough to arrive with your documentation, let's say the national ID of Romania. You will be required to be registered and show the certificate of regular residence [in Barcelona] [...]. And if you don't meet this requirement you cannot access the service (bcnA10).

This also means that even though irregular migrants' formal entitlement to basic social services is, in principle, uniform across the country, much depends on where exactly they live. Since the overall cost of welfare provisions tends to increase with their inclusiveness, financial constraints often preclude this kind of local investment in social cohesion, especially in the wake of an economic crisis and if it means spending money on people whose deservingness is increasingly questioned. The following accounts of a social worker (1) and a migrant community representative (2) reflect these limitations as well as the distinctiveness of Barcelona in this respect:

(1) It is also true that the City of Barcelona in recent years has stood out for having more money than other City Councils. The law says that local support depends on each city, so each city invents what it wants. In recent years, during the crisis [...], we have disposed of money to be able to do and cover things that in other municipalities, smaller or with another economic situation $[\ldots]$ could not be done. I have colleagues in the Prat [a municipality next to Barcelona] who don't even attend [irregular] immigrants at all. But this is not so much a policy of migration, but a policy of 'there is no money for almost anything' (bcnA20).

(2) What they did [in Barcelona] was the opposite: raise this provision so that all the people who used to receive [support] continue to receive it, and apart from that the ones below also receive it. [...] You put so much more money that everyone can get the food scholarship. What for? So that the one who had it and would lose it does not blame the immigrants that now he no longer receives it because of them (bcnA01).

\footnotetext{
${ }^{1}$ Art. 14(3) of Organic Law 4/2000, of 11 January, on the rights and freedoms of foreigners in Spain and their social integration, see: http://noticias.juridicas.com/base_datos/Admin/lo4-2000. t1.html\#a14 (last accessed 15/12/2017).
} 
Whereas in Spain and even within Catalonia irregular migrants' access to basic assistance can thus significantly vary from one municipality to the next, in the UK they officially have 'No Recourse to Public Funds' (NRPF) wherever they live. NRPF is a condition defined under immigration legislation that renders certain persons who are 'subject to immigration control' ineligible to receive any public support or benefit, including services administered directly by local authorities, like temporary housing, homelessness support or basic attendance allowances ${ }^{2}$ (Stephens et al., 2010; NRPF Network, 2011). While it also applies to increasing numbers of 'regular' immigrants holding a temporary residence permit, it is clearly a central element of the government's 'hostile environment' approach to irregular migration. The underlying rationale is that by increasing their risk of destitution, unlawful residents including many refused asylum seekers might be persuaded to leave 'voluntarily', even though a growing body of evidence suggests that this is generally not the case (Crawley et al., 2011; Refugee Council, 2012; CORAM, 2013). The resulting legal framework only acknowledges very few and narrowly defined situations mostly if minor children are involved - in which unlawful residents can avail themselves of public assistance: if a family's asylum claim has been refused but there are legal or practical barriers impeding their removal, they can qualify for (very limited) support from the HO. ${ }^{3}$ More generally, irregular migrants with minor children who are destitute or about to become destitute might be eligible for support provided directly by the LA, which has a duty under Section 17 of the Children Act 1989, to ensure the welfare of every child in need within its jurisdiction (NRPF Network, 2011; CORAM, 2013). It is important to note that LAs are only allowed to support unlawful residents where withholding such support would result in a breach of the child's - or a vulnerable adult' $\mathrm{s}^{4}$ - human rights. Where it is assessed that a LA is responsible for a particular family, however, support tends to go well beyond the rather basic and fragmented provision that local social services in Barcelona would be able to offer in a comparable situation.

Another policy element that significantly determines the effective accessibility of a service for unlawful residents and which clearly sets both cases apart is the existence (in Spain) and lack (in Britain) of an effective firewall between local social services and national immigration enforcement agencies. Unlike in Spain, UK immigration law places a legal duty on local authorities "to supply information for the purpose of establishing where a person is if the Secretary of State reasonably suspects" that a (former) resident of that area has committed an immigration offence. ${ }^{5}$ More specifically, the same law also requires the LA to inform the

\footnotetext{
${ }^{2}$ According to Section 115 of the Immigration and Asylum Act 1999. Primary and emergency healthcare and compulsory education are not classified as 'public funds' in this respect.

${ }^{3}$ Under Section 4 or 95 of the Immigration and Asylum Act 1999 (see CORAM, 2013, pp. 14-16).

${ }^{4}$ The Care Act of 2014 establishes a similar duty towards particularly 'vulnerable adults', whose needs do not just arise from their destitution but from a mental or physical illness or disability (NRPF Network, 2015).

${ }^{5}$ Section 129 of the Nationality, Immigration and Asylum Act 2002, see: http://www.legislation. gov.uk/ukpga/2002/41/section/129 (last accessed 15/12/2017).
} 
immigration enforcement agency if an unlawful resident requests support from social services (NRPF Network, 2011). The therefore often well-founded fear on the part of irregular migrant families represents a significant additional barrier to accessing or even approaching a service that they might well be entitled to, as a practitioner working for the Children's Society in London asserted:

There is a bit of reluctance that sometimes you find with families to even approach social services in the first place. So even when we sit down with them and explain the situation and the kind of support that they might be able to provide to them, and that it is the LA's duty to support them, then they are still quite reluctant. And I think that's because they don't want the Home Office finding out. And we always have to [...] explain that the Home Office will; you know, if we refer a family to social services it will be reported to the Home Office in one way or another (lonA22).

Several other interviewees also suggested that what they perceived as varying degrees of reluctance among migrant families generally seems to correspond with their actual deportability and their legal prospects of eventually being regularised.

Among the people I interviewed in Barcelona, in contrast, the corresponding firewall was generally perceived as intact. In combination with the comparatively smaller overall chance of irregular residence leading to deportation (see Sect. 4.1), this explains the much lower level of fear among irregular migrants to approach social services in the first place. The following accounts of two social workers I interviewed together (1) and an irregular migrant from Morocco (2) seem to confirm this:

(1) [Social worker 1] I think that they come here fairly calm in this sense. Some are rather demanding sometimes, it's rather the other way around: that they are mounting quite a show, and they are very demanding at times...

[Social worker 2] I think they are very aware that everything that is immigration depends on the central government and [that] we are only the City Council. Another thing is the level of exigency that they exhibit because of this message that they receive... that they are citizens of $B C N \ldots(\mathrm{bcnA} 20)$.

(2) [At social services] they nonetheless help people. Before, I didn't think this service was for people like me... because we don't have that [in Morocco]. I had no idea that there are people who help other people who don't have papers. You understand me? But thanks to God, Spain has this; [...] I didn't know anything about the rights in this country, [...but] little by little you find out (bcnB05).

In the UK, no equivalent right exists per se. It can only be activated under very particular circumstances and through a statutory assessment procedure that automatically reveals the claimant's legal-administrative situation to the national immigration authorities. As a result, most of irregular migrants' needs in terms of ad-hoc support either have to be covered within their own kinship or community networks or picked up by the Third Sector. The former tends to be unsustainable and due to a lack of scrutiny can increase already vulnerable individuals' risk of exploitation, mistreatment and abuse. The latter, in turn, puts additional pressure on already overburdened local community organisations and charities struggling to provide mainstream poverty relief, food hand-outs or night shelters (Butler, 2016). During my time as a volunteer for a local migrant advice and support centre, the rapidly 
growing demand for the weekly service repeatedly made it necessary to replace the open drop-in session with a system that required 'visitors' to queue, sometimes for several hours, in order to be seen by a professional advisor. When I resumed my volunteering at the centre in October 2019, the weekly open drop-in service had been limited to 20 visitors per session and was allocated on a first-come-first-serve basis. In practice, this meant that many demonstrable needs could not be responded to; and that often very vulnerable people coming from all over London, including many families, would wait in front of the venue from very early morning or even spend the whole night on a bus or in a nearby park in order to arrive early enough to be attended. It also became increasingly difficult to refer people to specialised agencies and services (both private and public), and this was quite often precisely due to limited capacities for dealing with foreign residents without or with precarious immigration status.

\subsubsection{Irregular Migrants' Access to Substantial and Longer-Term Support}

Both in Britain and Spain most mainstream social benefits are under central government control - exercised by the (UK) Department for Work and Pensions or the (Spanish) Ministry of Work and Social Security, respectively. Foreigners in irregular situations are generally excluded from the pension system, regular unemployment support and the provision of social housing, as well as child, family and other benefits or tax credits. In Spain, the public welfare net also relies significantly on minimum income (support) schemes administered at the level of the 17 Autonomous Communities, which also determine the corresponding eligibility criteria and payment rates. This non-contributory, means-tested but generally low financial support ${ }^{6}$ precisely aims at the social inclusion of those not (or not anymore) covered by the national unemployment and social security system. In exchange for support the beneficiaries are obliged to work towards their occupational (re-)integration.

The Catalan Minimum Insertion Income ('Renta Minima de Inserción', RMI) can be claimed by anyone who can prove a lack of financial means and social security coverage as well as continuous registration in Catalonia during the preceding two years. In addition, and unlike ad-hoc support by social services, eligibility is also strictly contingent on legal residence in Spain. ${ }^{7}$ In this case it is Catalan law that explicitly extends irregular migrants' exclusion from the contributory into the non-contributory sphere of mainstream social security, and from the national to the local level of service delivery. Interestingly however, while this puts clear legal limits on the provision of more substantial services and resources to migrants living irregularly in Barcelona, the logic of local residence as the

\footnotetext{
${ }^{6}$ Rates vary but remain significantly below the national minimum income threshold. ${ }^{7}$ Explicitly set out in Art. 6.1(b) of Ley 10/1997, de 3 de juli, de la Renta Mínima de Inserción.
} 
principal criterion of eligibility is thereby not completely dismissed. A social worker gave me a good example of this:

The RMI is regulated by law, like unemployment benefits, and the first requirement is to have been registered for two years in Catalonia and have permission [to reside] at the time of the application. In other words - and I did have cases, especially where permits are obtained because of a serious illness [...] which is a residence permit but no work permit once they have the residence permit and [if] they have been living in Catalonia for two years, they can [apply for] the RMI, from the first day they have their NIE in hand. But it's a legal requirement [to] have a NIE. If you don't [...] you cannot access it (bcnA22).

This means that irregular but officially registered residence in a locality does count towards the minimum residence period required by Catalan law. The length of this residence is measured via the municipal register (see Sect. 4.2), which does not even record its lawfulness under national immigration law. What matters is the effective previous residence in a place. It also shows that the idea of irregular residents nonetheless being 'citizens of Barcelona' - which one of the social workers quoted earlier had referred to - is not just an empty message they receive but is also reflected in the legal framework itself (cf. Chauvin \& Garcés-Mascareñas, 2020) and thus only has to be effectively implemented in everyday practice.

In the UK context, the official message that irregular migrants - as well as public service providers who are confronted with their needs - receive, is very different: They are very explicitly not considered citizens (neither of London nor the UK) and their accessing of any state support or social assistance - even if provided locally can only constitute an exception from the general rule that demands their absolute exclusion. In this sense, the (administrative) function of certain migrants' having 'No Recourse to Public Funds' is also a symbolic one. It demonstrates to the wider public as well as to service providers that because of their irregularity (or limited right of residence) some residents simply cannot benefit from any public spending. This not only hides the fact that they do have access to schooling and basic healthcare, for example, but also generates confusion about the relationship between NRPF and so-called Section-17-support for vulnerable families in irregular situations. The following quotes from interviews with a representative of the Children's Society (1) and a local Councillor responsible for social policy and housing (2) demonstrate this:

(1) I still hear all the time from [LAs'] Duty and Assessment teams that 'oh no, no, we can't support them, they are NRPF'; and when you say, 'oh well, that's not correct, you need to look into it and do a human rights assessment', they don't know what we're talking about and they are just like: 'Oh no, no, no, we can't support, if they've got NRPF we can't provide any support' (lonA22).

(2) We have got this issue in [the Borough], which is happening in lots of other London Boroughs as well, where you have people who have come here, who don't have Leave to Remain but are still here, and there is some EU legislation which I am sure you are aware of, where if they have children that are born here, then they can claim money while their cases are being sorted out (lonA21).

Fact is that neither does the child have to be born in the UK (or be a British or EU citizen) nor is it EU law that establishes this entitlement; but what these quotes show quite well is how difficult it is - even for expert practitioners and politicians 
working in this field - to understand that UK legislation not only allows but can even demand the provision of social assistance to what the government keeps calling 'illegal immigrants' with 'No Recourse to Public Funds'. This is in line with findings of Jonathan Price and Sarah Spencer (2015, p. 29) whereas the NRPF-label increases the likelihood of certain physical or mental health needs and even child protection concerns to be inadequately addressed by statutory services. Quite clearly, the exclusion of certain migrants threatens to undermine the important role that social services have to play for society as a whole (Schweitzer, 2020).

It is also important to recall that Section-17-support is meant to be a transitory measure until certain irregularities of a client's situation can be resolved and his or her needs then covered by mainstream support or benefits. The legally complex and protracted situation that irregular migrant families usually find themselves in, however, often means a quite substantial and rather persistent financial burden for the supporting LA. Data collected by Price and Spencer (2015, p. 51) suggests that more than one third of NRPF cases remain in LA support for between one and three years. In the absence of any additional support from the community or charities, the LA is supposed to cover the full costs of living (including privately rented accommodation) until the immigration case is resolved, i.e., the family is either regularised or deported. Support cannot be refused solely on the basis of insufficient municipal funds, nor will the LA be reimbursed by the state for these additional expenditures (NRPF Network, 2011). Based on the argument that this would create an additional pull-factor for irregular immigration to the UK, the Home Office has repeatedly rejected various local authorities' requests for reimbursement (Price \& Spencer, 2015, p. 23). This represents an additional challenge for LAs, not only in terms of their responsibilities towards their (regular) residents but also as organisations whose legitimacy hinges on democratic elections, as one Council worker emphasised:

There is a skewing of resources away from the types and categories of people that those legislations were originally designed to help, towards people whose only reason [for] approaching support is that the government says they can't work, and they can't claim benefits. And that is problematic for a political organisation, and particularly at a time when it has to make huge cuts in budgets. We have to be mindful of how that is received and understood by our electorate; that is hugely problematic (lonA30).

Interestingly, what really underpins a particular LA's statutory responsibility to provide Section-17-support to a destitute family is - just like in Barcelona - their effective residence in the neighbourhood, which is independent of formal or political membership. In practice, however, support can only be provided following complex assessments of the family's destitution, the child's concrete needs, and of whether or not a human rights breach would ensue if support were withheld. This makes it very difficult for families to enact their right to such support and creates a significant divergence between law and practice, as two NGO practitioners who regularly help families through this process told me:

There are a lot of discrepancies between different LAs and also there are a lot of families who just don't know that they can access that support. [...] And if they do know about it, they might still be denied and wouldn't necessarily get the legal support to challenge the LA 
to be able to actually exercise their rights. So that's the kind of area where I think you see the legislation is there, but the practice is a very mixed picture (lonA10).

[LAs] are going to want evidence of immigration status, so if you have put in a claim [for LTR] they want the acknowledged letter and they want the actual application, [...] they want evidence of destitution, so if you are being evicted they will normally want to wait until you get the eviction warrant, or if you are staying with friends and they are asking you to leave then letters from the friend or letters from people who have been supporting you (lonA04).

In spite of how difficult it is in practice to gain access to this kind of support, the overall financial pressure that it particularly implies for LAs in London has risen steeply over the last couple of years. What certainly has contributed to this development is that many of the 'hostile environment' measures have made it more difficult for migrants in irregular situations to support themselves. Usually as the very last resort, after all other sources of support have been exhausted, more and more families have to fall back on support from local social services, as one of the social workers I spoke to noted:

Every time they have a refusal from the HO, or their ability to exist outside contact with public services is restricted - so every time there are cuts in the right to work, every time there are changes in access to housing, every time there are rules coming in about the shadow economy - it funnels all down to the LA. [...] So the issue around managed migration and its functioning or lack of functioning has a massive impact on local services and [is] a drain on our resources, and it's getting worse all the time (lonA30).

While there is no evidence that shows that this approach has provoked the "voluntary departure' of a significant number of irregular migrants, as the government hopes, it does curtail the ability of local institutions to protect the most vulnerable members of society from destitution, abuse and social exclusion, let alone support their successful integration. The following section looks at how individual streetlevel bureaucrats who either administer or provide social assistance at the local level perceive and deal with these challenges.

\subsection{Negotiating the Effective Limits of Vulnerability, Deservingness and Immigration Control: The Role(s) and Agency of Social Assistance Workers}

Like in the spheres of healthcare and education, and as shown by Joanne van der Leun (2003) and others, most of the everyday gatekeeping is done by those actors who locally administer social assistance and protection, rather than those actually providing such services to the user. Particularly in the case of social assistance, however, even the initial determination of a client's eligibility often requires professional training and experience. Although this, in practice, slightly blurs the distinction between administrative (e.g., reception) staff and professionals (social 
workers), I uphold the analytical differentiation between administrators, professional providers, and managers of irregularity.

\subsubsection{Administrators of Social Assistance and Protection}

Particularly in the British context, the strict formal exclusion of irregular migrants from mainstream social assistance and protection also significantly limits the discretion of local authorities and individual welfare workers to effectively renegotiate access to locally funded support measures. Whereas the municipality of Barcelona has - with a view to maintaining social inclusion and community cohesion - extended basic social service provision beyond the scope of national and Catalan law, UK legislation generally precludes such extension of local welfare rights. ${ }^{8}$ The only exception is where LAs themselves assess that not addressing the needs of a destitute child (or vulnerable adult) living within their jurisdiction would amount to a human rights breach. While these assessments open up some room for individual discretion, the tremendous financial pressure under which such decisions have to be taken renders inclusionary interpretations of the corresponding rules rather unlikely. The following accounts of a Council worker (1) and an NGO practitioner (2) clearly reflect both of these aspects:

(1) There is a lot of... opportunity for discretion and for interpretation, and people can be lucky and perhaps access somebody who is in a good mood that day and who might feel like allowing them access to something without perhaps probing so deeply. But more generally it seems that increasingly people are meeting gatekeepers who are very worried about not exceeding what they are allowed to give and very concerned about making sure that all the procedures are very strictly adhered to; and that can result in people being actually excluded from a service or a provision to which in fact they were entitled (lonA27).

(2) Very often we see gatekeeping practices; because the money spent on families through Section 17 is not reimbursed by central government [but] comes out of [LAs'] own budgets there is a lot of pressure on them to kind of hold their money tight. So, they are unwilling to spend it and very often if you start carrying out an assessment you have to eventually provide support. So, the easiest way for LAs to avoid spending money is just to say 'there is nothing we can do' at the very first stage. And they do things like threaten to take children into care, saying it's not their responsibility but another LA's responsibility, saying 'oh you have got NRPF, so we can't help you' or 'you got no leave to remain' ... you know, whatever it is, they will sometimes just think of an excuse (lonA04).

The study of Price and Spencer (2015, p. 35) highlights the wide range of reasons given by Council workers for rejecting applicants already at screening stage, and their findings underline the fact that once a case is admitted for a statutory needs assessment the most likely outcome is that support will have to be provided. Other

\footnotetext{
${ }^{8}$ Section 7(1) of the Local Authority Social Services Act 1970 establishes that "[1]ocal authorities shall, in the exercise of their social services functions, including the exercise of any discretion [...], act under the general guidance of the Secretary of State", see: http://www.legislation.gov.uk/ ukpga/1970/42 (last accessed 15/12/2017).
} 
reports show that the general reluctance of LAs is also underpinned by a widespread perception that offering support to a family that lives in the UK unlawfully will reduce the likelihood of them returning 'voluntarily' (or at all) to their country of origin (CORAM, 2013). One of the Council workers I interviewed clearly expressed this feeling:

Increasingly LAs are being seen by applicants and [their] advisors, to a large extent, as a means by which someone, particularly if they have a child, can continue to remain in the UK, but without having to be involved with the Home Office, and that is in itself a huge issue for us. Because actually that's not our role, our purpose is not to facilitate someone to be allowed to stay, when they have reached the end of the road as far as the Home Office is concerned, just because actually removal of families is technically difficult; and nor is it our role to facilitate them being able to make multiple applications, which they wouldn't be able to do if they weren't being supported by us (lonA30).

For most families in this situation, however, return is not a viable option and "very often [they] just go and live in destitution in order to avoid [...] dealing with this [social service] department that they see as really hostile" (lonA04), as an NGO practitioner described her experience. Those who do make such claims increasingly have to be accompanied by a privately contracted lawyer or specialised NGO, in order not to be 'put off that easily', as a representative of the Children's Society emphasised:

When they're going on their own, those tactics are often used. So, what we do is we tend to put a written referral in, so that there is a paper trail of the act and all their circumstances have been documented, it's written, it's been sent in through the correct channels and we can chase it up with them (lonA22).

Just like the official exclusion of irregular migrants living in London is not as straightforward as their NRPF-condition suggests, also their formal inclusion in the case of Barcelona is mediated through administrative gatekeeping practices that can lead to (informal) exclusion. Basic documentary requirements - while necessary in order to establish service users' identity - represent the first potential barrier, as the director of a social service centre (SSC) in Ciutat Vella noted:

Well usually when they come to ask for an appointment, they identify themselves. We ask for a document to identify them, to know who this person is. And so, they show us an identity card [DNI], or their residence permit, or the passport. If someone presents a passport it's because s/he doesn't have anything else, so... that already tells you. [...] It is also not to duplicate, so when you come with your DNI or your NIE or your passport and we open your file, we can see if you are being attended in [another SSC] at the same time. What we are not going to do is attend you in two places at once (bcnA20).

While this is a common way in which welfare bureaucrats including receptionists regularly 'happen to find out' about the irregularity of a (potential) client's residence in Spain, it does not prevent them from normally administering that person's access to at least the most basic forms of support, as another interviewee clarified:

People can come and say, 'well I'm here but I don't have a [residence] permit, I only have a passport', so they identify with their passport and we open a file with the passport number, just like someone else with the DNI or NIE. And from there they are treated just like any other person but within the limitations that the law imposes (bcnA22). 
What he also hints at, is that the legal framework leaves less room for renegotiating irregular migrants' access to more substantial support like mainstream benefits. Only in some cases can these limitations at least partially be bypassed or attenuated by individual workers taking into account the client's specific situation and social context and thus interpreting the rules more flexibly, like in the case of mixed-status families:

In the case of [irregular migrants] it is obviously more likely that they remain at the primary level [of support], because since they will only qualify for sporadic assistance, you cannot really make a work plan... But if it's a family where one [partner] doesn't have a residence permit but the other does, then you can make a work plan, and you can even process a benefit like the RMI for the person who has the permit, even if the other is administratively irregular (bcnA21).

Local social services in Barcelona are not only 'allowed to work with' clients in irregular situations, but they can also play a crucial role within the process of their regularisation and thus the overall management of (irregular) migration to Spain. Part of this role consists in facilitating municipal registration for people without a permanent address, as an employee of a CSS in another district of Barcelona explained to me:

We can produce a document that says that we know that this person resides in the city, and with this document and an ID - which can be their passport - they go to City Hall or the local municipal office in their district and there they are registered 'without fixed abode'. This has the same effect as a registration with permanent address, only that it won't show your address and so you won't receive the letters that City Hall may send you. For example, here in [the district] the address of someone registered 'without fixed abode' is that of this centre, so of course there are thousands of letters that are lost, except someone tells you, or is well known, or comes to collect them, so it's very complicated (bcnA22).

This arrangement thus creates some extra work for local welfare bureaucrats and requires a certain level of cooperation and information exchange with City Hall; but it is generally not perceived as part of immigration control, as the following extract from an interview with two social workers indicates:

[Social worker 1] Immigration control would be if I were forced to report this person who is irregular and then the police came and took him...

[Interviewer] ...but that doesn't happen?

[Social worker 2] No. That's what I was trying to explain: It's that the whole issue of immigration... depends a lot on how it works in any particular country of Europe and the issue of social services is sometimes linked to immigration, whereas here it's a part that is disconnected $[\ldots]$

[Social worker 1] And obviously they would stop to come; if I tell you that I have to inform [the police] you are not going to come to me. Or if I put you into the system and that [raises a red flag] and the police comes to your house... well, you better not come (bcnA21).

The latter statement once again highlights welfare bureaucrats' awareness that much of the effectiveness of social service provision hinges on the clients' trust. Trust in general and particularly in the promise that without their consent no information about their identity, immigration (or other) status or whereabouts will be passed on to the police or other authority. As already mentioned, this is what fundamentally sets the case apart from the British context, where no such firewall is in 
place. Instead, the legal obligation to inform the immigration authority of any 'reasonable suspicion' of a potential immigration offence extends into the sphere of local social service provision, where it has important implications for how individual gatekeepers deal with this client group. The internal guidance from a London Council's Safeguarding Children Board on what it calls "Inter-agency Information regarding NRPF Families" clearly states that "[i]f there is a family that comes to the attention of the Local Authority and it is discovered they are in the UK unlawfully, then there is a legal duty on the Local Authority to inform the Home Office of their whereabouts" (emphasis added). In practice, such information can be exchanged through so-called 'local immigration teams', which the UK Border Agency established in 2008 as a way of "bringing our people closer to the communities we serve" (cit. in Vine, 2010, p. 7; see also NRPF Network, 2011, p. 12). In addition, and following the initiative of various LAs in London, the NRPF network set up a computerised system called NRPF connect, ${ }^{9}$ which a Council worker described to me as

a database used by LAs to record the cases that they are supporting and to share that data with the Home Office; and indeed, for the Home Office to provide immigration information to look at how they can progress cases, so that you move them on towards grants of status or indeed move them on to removals and start family removal processes [...] where we feel that there are no barriers, and that return should be pursued (lonA15).

At the time, LAs were charged an annual fee of $£ 2000$ for using this system while the Home Office since the beginning contributes to its maintenance. What already became clear is that this cooperation was not just based on a one-way obligation, but rather seems to benefit both sides: On one hand, it certainly helps the Home Office to keep track of or detect new cases of unlawful residence, including people who have 'absconded' following the rejection of their claims for asylum or LTR. On the other, it allows the LA to reduce the pressure on its welfare budget by discouraging potential clients from even applying for support. In the meantime, the 'annual user charge' increased to $£ 2.500$ (for the 'standard service'); and in 2019 alone, LAs using NRPF-Connect "saw an overall reduction of $£ 100,000 /$ week (10\% over the year) due to a decrease in the number of households receiving support". ${ }^{10}$ In addition, LAs can verify not only the immigration status of those who do apply, but also their declarations regarding any alternative sources of support that could prevent their destitution and thus absolve the LA from its duty towards them, as several of my interviewees, including a case worker for the Children's Society, mentioned:

There're a few things that social services tend to use to try and put people and families off, and the first one being that connection with the Home Office; $[\ldots]$ and there is fear sometimes among families, and particularly when their [immigration] claim is around them having family and friends and a private life here in the UK and then they approach social

\footnotetext{
${ }^{9}$ The project was initiated by the NRPF Network in 2006 and by September 2016 had been joined by a total of 45 local authorities, including 25 (of 33) London Boroughs, see: http://www.nrpfnetwork.org.uk/nrpfconnect/Pages/default.aspx (last accessed 15/12/2017).

${ }^{10}$ See: http://www.nrpfnetwork.org.uk/nrpfconnect/Pages/default.aspx\#join (last accessed $15 / 07 / 2020)$.
} 
services saying 'I've got no support, no family or friends who can help me out'... I think sometimes there is that worry that that might actually have a negative impact on the outcome of the claim (lonA22).

Having this close relationship with the Home Office, in combination with the slow decision-making of the latter, thus seems to push individual gatekeepers to question even more the deservingness of irregular migrant families and to treat their claims as illegitimate or at least suspicious. The following accounts of an NGO practitioner (1) and a Council worker (2) exemplify this:

(1) If they [the immigration authorities] are taking four years to make a decision and the person isn't able to access any services in the meantime, nor to access benefits or work, then that's going to fall on the LA. And I think there is an incentive in a way for the LA to inform the Home Office about a person who is 'appeal rights exhausted', because then they would speed up removal and they won't have to support them anymore (lonA16).

(2) Our relationship with the Home Office is an interesting one, because part of it is working together. We are two statutory organisations, [...] we are spending tax-payers' money on providing financial support and we are keen to make sure that if there is a 'genuine claim' - well that's Home Office terminology, but you know what I mean by 'genuine claim' - that they are granted [LTR], and of course if there isn't then you pursue removal; but we don't like limbo, we don't like people just hanging about. [...] So, the argument for data sharing, or not the argument but the reason, is that a LA can't actually fulfil its statutory duties without knowing someone's immigration status, because we need to know whether those exclusions apply (lonA15).

Since in these cases the immediate costs of irregular migrants' limbo have to be borne by LAs, getting them 'resolved' also becomes their number one priority, even though it primarily depends on the Home Office to sort out the underlying immigration issue. Arguably, this leads to a dangerous conflation of the claimants' destitution with their (potential) irregularity. In its guidance for LAs the NRPF Network (2011, p. 20) explicitly highlights their duty to "consider resolving the family's destitution by offering assistance in returning the family to the parents' country of origin". At least from an administrative perspective there is thus a significant overlap between the destitute family's need for social protection and the need for more efficient immigration enforcement. A single mother from Nigeria whose child was born in the UK after she had overstayed a visitor's visa in 2013, experienced this overlap first-hand when she approached social services:

So, if it's their [duty] to provide for the baby, why would they provide for the baby without the mother? What they are saying is that the mother has to be... has to have an application with the Home Office, or have LTR... that's when they will provide, but without that they can't provide [support] for the baby (lonB11).

This link plays a crucial part in how local welfare bureaucrats in the UK are encouraged to see their clients' immigration situation as part of their own work or even the basis for any dealings with them. In the following section I will look at what this conflation means in relation to social work as a professional duty rather than merely a service to be financed and administered on the basis of legal entitlement. This will also expose the much subtler mechanisms that ensure that even in 
the less 'hostile' environment of Barcelona irregular migrants can never be effectively integrated into local support systems.

\subsubsection{Professional Providers of Social Assistance and Protection}

In both contexts, most of the professionals I spoke to did generally perceive irregular migrants as (a small) part of their clientele, even though not always as deserving the same level of support as other local residents. Particularly in relation to those quite central elements of their work that do not involve an actual transfer of financial resources - like individual counselling and child protection - immigration status matters the least (Cuadra \& Staaf, 2014). This is also true for the generally more restrictive UK context, as one social worker pointed out:

For example, the general child protection teams are obviously still delivering a service to everybody. If a hospital rings up and says we have got a child who has been admitted and they seem to have some non-accidental injury, or a school that rings up and says that a child comes in always very hungry and very dirty [...] or looks like it's being harmed by its parents... you know, they go under the remit of the general safeguarding and child protection teams, regardless of any immigration status (lonA27).

At the same time, and particularly in Barcelona where these interactions are much more normalised, social workers tend to perceive a client's lack of immigration status as something external but also potentially disruptive to the close and ideally longer-term relationship they seek to establish with the client in order to effectively do social work. The following extracts from interviews with two social workers (1) and a social educator working for a local NGO (2) reflect this:

(1) [Social worker 1] The whole issue of irregularity does not depend on us. It is a state issue. We are not going to give these people a residence card... because that depends on the state, but obviously...

[Social worker 2] ...it leaves us in a very assistentialist position, from the outset.

[Social worker 1] Yes... yes exactly that (bcnA21).

(2) [We] have to initiate a process with the person and [...] that process has to be longer, also to be able to make our intervention a bit more comprehensive; because if not, it will remain very assistentialist and will always just be a sporadic relief here and another one there... but it won't be an intervention that would lead towards inclusion and towards integration (bcnA06).

Being able to establish an agreed, longer-term 'plan' for working together with the client is important because it helps social workers to justify the difficult decisions they have to take throughout this process, like whether or not to grant any particular subsidy, as another social worker explained to me:

When we say no [to a client], it's normally because the person didn't stick to the work plan, and since these are not statutory benefits, they depend a little bit on the 'deal' you make with the user in relation to the work plan [...]. So, if they're just going to come here and ask 
for money... then no. We try to do social work in the sense of committing people to this [work plan] (bcnA20).

An important insight of Lipsky's (1980, p. 152) ground-breaking study of the workings of street-level bureaucracies was precisely that "orienting services toward cooperative clients, or clients who respond to treatment, allows street-level bureaucrats to believe that they are optimizing their use of resources". A housing officer I interviewed in London put it this way:

Sometimes I do think that depending on how the person presents - but this is more generally, it isn't necessarily to do with migrants only - does determine your response to that person as well. So, if people are prepared to work with you to try and find something in the private rental sector, to work with you to try and... you know, to give you all the information you need and not to be obstructive about things, actually I think we are much more willing to be able to try and meet more of their need in a certain sense (lonA30).

Especially if social services are known or expected to work closely with the immigration authority, a client whose stay in the country is unlawful has a very good reason not to provide all the information and is certainly more likely to come across as being 'obstructive about things'. This is one reason why the "increasing connection between social services and Home Office [...] doesn't seem to sit right with a lot of practitioners" (lonA22), as one of my interviewees put it. While some of the social workers I spoke to in London admitted that the lack of a firewall gives them a certain power over some of their clients, they generally tried to downplay their own role in informing the Home Office about a suspected immigration offence:

We say it right up front, not as a threat but a piece of information that is: 'you need to take this into account as to whether you wish to proceed or not'. Because it's important that they know that there is a consequence, potentially. But $[\ldots]$ the reality of the situation is that there are so few [family] removals that they don't see that as much of a risk, I don't think. It certainly hasn't had much of a deterring effect on people... withdrawing or walking away from an application for assistance from us (lonA30).

Personally, I have not heard of any [colleague] who has volunteered such information, other than the [client's] address, which is actually not even done by us but by somebody in the finance department who monitors the grant claims, and occasionally we get asked a question like... if somebody is not sure about the address or thinks that something hasn't been recorded correctly or whatever... But that isn't even our job. That's the job of the finance department (lonA27).

In Barcelona, on the other hand, neither finance departments nor social workers themselves face any obligation (nor open encouragement) to notify immigration authorities of their dealings with unlawful residents. The following dialogue between two of them reveals some uncertainty about the corresponding rules but also highlights their reluctance to accept eventually having to report cases of irregular residence, even though they do perceive it as part of their work to potentially act as a link to law enforcement:

[Social worker 1] I think on paper we should report situations that are... illegal, [...] like when a guy tells me that he sells drugs.

[Social worker 2] Yes... legally you have to report it; you would have to report it. 
[Social worker 1] But if he tells us 'I am administratively irregular' ... would we have to report that?

[Social worker 2] I don't think so.

[Social worker 1] Look [...] we don't want to know. In any case, I don't know if by law we are obliged, but somehow, consciously or unconsciously, we object ['nos hacemos objetores']. No one is going to report that, [...] just like the guy who says that he [is a drug dealer]: I will not call the [police] to tell them, no. Why? Because I understand it is a confidential space. Another thing is if someone tells me that $\mathrm{s} / \mathrm{he}$ has killed someone, or is being beaten by the partner, or that a child is being mistreated... Obviously I am bound to report this, and I will see if I do it immediately or if I will work with [the client] so that s/ he takes a series of decisions... (bcnA21).

The fact that a firewall prevents exchanges of certain information between social services and immigration authority, however, does not automatically mean that irregular migrants can be treated as 'normal' services users. As the Catalan case shows, there are other mechanisms that ensure that social workers will perceive them as a client group that is 'more complicated' to deal with. What according to most social workers I spoke to in Barcelona troubles their relationship with irregular migrants in particular, is the general expectation that social assistance should be geared towards finding employment or at least enhancing employability. This demand increasingly pushes them to direct their own efforts at clients who might find a job in the near future, rather than those who are not even allowed to work:

[Social worker 1] Since there are so many unemployed people and so many foreigners who already have residence permits, to bet on someone without a permit... some time ago you could consider doing that, but now it has become a very remote possibility.

[Social worker 2] Yes, it's more complicated to do that.

[Social worker 1] Because... okay, I'll bet on you and offer you a training, and then? If you are not going to get a work contract... I mean, it's tough, but I will dedicate my efforts to another person who afterwards can get a work contract (bcnA21).

Also in this case social workers thus tend to 'orient' their services and resources to those clients who can 'respond' to these measures in the way that is expected of them. To focus on the formally unemployed rather than their irregular counterparts, thus seems to make sense for them but it also makes them realise the limits of their own professional discretion:

\footnotetext{
We will always look for solutions but what we cannot do as social services is if someone doesn't have the right to receive the RMI or another subsidy established by law, we cannot ignore this. We can give them a grant, generally during a maximum of six months [...], but we have to justify this a lot. To give someone a grant to pay for a room I have to explain very well and justify and justify and be convinced that after that there will be a solution for that family, otherwise... So, with those who have just arrived and within the next three years [until they can apply for regularisation] will not be able to work... I cannot even consider that; it's not going to be approved (benA22).
}

Often, the only way they feel they can help in these cases is by referring the client to Third Sector organisations, where they can at least enrol in language or other training courses (see Chap. 6). While social workers were rather split about the actual utility of these courses and aware that they sometimes create false expectations, they also saw them as a way to start working towards regularisation. After all, 
"the objective is always the pursuit of the documentation" (bcnA20), as one of them put it.

What became clear in both environments is that professionals dealing with irregular migrants tend to shift at least part of their attention away from the social needs of these clients and towards their irregularity. The latter, as I argued (in Sect. 4.1), is a condition framed by the possibility of being either regularised or deported. On one hand, social workers thus regularly have to take into account the actual prospects of their clients being granted a residence (and work) permit as one possible solution to their situation. Also in the UK, according to the NRPF Network's (2011, p. 37) guidelines for professionals, finding a solution for a family "may also involve exploring opportunities to apply for LTR with the assistance of an immigration solicitor". The following quotes taken from interviews with a social worker in Barcelona (1) and an NGO practitioner in London (2) highlight that this often poses the difficult question of how long support can and should be maintained:

(1) What is true is that these cases of people without papers but with children present dilemmas. They present dilemmas in the sense of until when you maintain a situation of irregularity given the difficulty that this person can put herself in a process of regularisation... So, until when should we [support them]? (bcnA21)

(2) We have a case at the moment of a woman who has a child that will be seven in June, and in June she will be able to make her application based on that, but not within the next six months, so... you know, what does she do until then? [...] In fact, the LA was supporting her, and they terminated support, and it seems unlikely that she would be able to challenge that [...because] you need an exit strategy. So, in her case it would probably get somewhere because it's only going to be six months, but if you got a person with a two-year-old, they are not going to have any claim until the child is seven, and so that would be too long (lonA04).

On the other hand, social workers are often expected to (also) consider the possibility and likelihood of their clients' returning or being deported to their country of origin. Particularly in the UK this happens quite systematically - although without any statutory guidance or training (Price \& Spencer, 2015) - and often even before having properly assessed a family's actual needs. The following account of a social worker clearly reflects this nexus, which in itself becomes an argument for working closer with the Home Office:

The Home Office will provide information about whether there is a barrier to removal; that's really what we are looking for in the information from the Home Office. If there is no barrier to removal, then you could be [...] trying to do a child-in-need assessment and a human rights assessment to offer tickets home, as an... as that's being the limits of your powers. But if there is a barrier in place [...] then it's not going anywhere, so you are not going to be able to discharge your social services duties by offering tickets home, but you are back to thinking 'is the child in need because the child is destitute?' So, it changes our assessment process; the information from the Home Office will change our assessment process (lonA15).

Notably, also some of the professionals I interviewed in Barcelona mentioned that when dealing with irregular migrants they would consider - and sometimes discuss with their clients - the possibility of return. They did not, however, perceive 
return as an option that they, as social workers, could prescribe, let alone enforce, as one of them explained:

It's not that we are expulsing these people, but in the end, we have to make an inevitable reflection with the person of "what is your life plan? What is your migratory project? What options do you have? Until here we can help you: you can get [food vouchers] and such... but what about the future? What happens if you go back to your country? Is that an option? Could you go back...?'. [...] And there are people who say, 'Well actually, this is not what I have expected' - 'Well we can help you to return... do you want that?' - 'No, no, because despite everything I' $m$ better off here, I am better off under a bridge than where I came from' - 'Okay then, nothing, we will try to do what we can'; and that's it (bcnA21).

That not all such situations follow the same plot, has recently been shown by Ioana Vrăbiescu (2017), who documents cases specifically of Roma migrant children in Catalonia being taken into state care in order to push their families to consider the 'alternative of voluntary return'. Independent of the means and amount of effort that individual social workers put into encouraging their clients to return, however, there is a crucial difference to the UK, where the Immigration Act of 2016 specifically aimed to further restrict irregular migrants' access to section 17 support by limiting it "to those who are destitute and face a genuine obstacle to leaving the UK" (Home Office, 2016, p. 3). In Catalonia, the fact that somebody receives local support has no impact on how the state handles their immigration case; nor will a migrants' decision against 'voluntary' return have any systematic bearing on their entitlement or access to social services.

That said, several of the social workers I interviewed in each city also described their clients' irregularity as an additional source of vulnerability, and thus perceived it as part of their professional duty to address the inequality that underlies this condition:

When we are dealing with a person who is undocumented, we know that s/he is in a situation of a lot of... vulnerability. S/he is much more vulnerable, isn't s/he? And s/he will not be entitled to various types of benefits... (bcnA20).

At the end of the day, we have signed up to a profession where we are meant to be... addressing the imbalances of society, which is all about advocating for the most vulnerable. Whether they happen to be migrants or whether they happen to be disabled people or whatever, isn't so much the point. And we should be pushing towards a rebalancing of these... these discriminations and, you know, things that people are experiencing, and not making them worse (lonA27).

For Lipsky (1980, p. 151) it is one of the paradoxes of street-level bureaucracy that although individual bureaucrats "are expected to treat all people in common circumstances alike" it is precisely what he calls 'client differentiation' that enables them to rationalise "the contradictions in their work". That their everyday professional practice often requires them to "do for some [service users] what they are unable to do for all" (ibid.) seems particularly true for social workers. Where available resources are scarce, trying to ensure a fair distribution can thereby easily trigger existing tensions between various ethnic (or other) groups that make up the target population, as my interviewees in both cities were also well aware: 
We have to be careful about how someone who has no right to be in the UK gains access to social support, compared to someone who is here [legally] and tries to make an application as homeless. So, we have to be careful about our judgements as well, about setting precedents that appear to favour groups that have arguably less need and arguably less entitlement to expect a service than people who have an argument to expect a service. That [...] is a very difficult line for us to find on a case-by-case basis; it's hugely problematic (lonA30).

When you say no to [a client] based on your professional judgement $[\ldots]$ you will either hear 'you are only giving it to the [foreigners]', or vice versa, that you are a racist. They will always tell you something, and always normally in this sense, isn't it, whether it's someone from [here] or from outside. That's our challenge (benA20).

Particularly in the case of Barcelona, where the legal framework leaves more room for individual social workers' professional discretion, these and other external pressures constantly interact with their own strategies for identifying those clients that are more deserving than others. The following passage of an interview with two social workers exemplifies this:

[Social worker 1] The more experience you have [...] and the more capacity to reflect and see the complexity of [a client's situation], you will have a different way of acting, and a different outlook.

[Social worker 2] And the professional judgement gives you a lot of leeway. Depending on how you are - more giving or less giving - and the vision you have of social work, or of what the person deserves or doesn't deserve, or what s/he has to do or shouldn't do, ...you can grant lots of subsidies or you can grant few. The subsidies are there, but you use them or don't use them, that's the reality [...]

[Social worker 1] Yes, when I close the door of my office, after all it's the person with me. I have an institution behind me that says, 'you can do this, and you cannot do this', but I am a professional with a judgement, and I have a lot of autonomy to exercise this judgement, according to which I will mobilise or not the resources that I have behind me (bcnA21).

This autonomy can also very easily be used to unlawfully exclude someone, especially if the likelihood of facing a legal challenge is low, as the same interviewee later clarified:

If I am hostile and tell that person that s/he has no right to anything and that person accepts it s/he will go out through the door and will not appear again, and no one will find out. I can then write what I want in my data record and that's it. Whether the person will complain... well, $[\ldots]$ it will also depend on $[\ldots]$ the capacity that s/he has in the given situation to make a complaint, to mount a show, or not (benA21).

In the UK context, where the local institutions that social workers 'have behind them' are themselves more constrained in responding to irregular migrants' claims, the room for professional discretion is much more limited, although never completely removed. Eligibility for Section-17-support, for example, often hinges on little more than the social worker's professional judgement of the applicant's credibility, as one of my interviewees in London noted:

The problem is that when people apply for 'no recourse', the burden of proof initially is on them to show that they are in fact destitute, that they are in fact who they say they are, that they are the parent of the child, that they are... all kinds of things. Now, sometimes [...] there is very little evidence that they can provide as to who they are, where they are living, particularly if they are subletting illegally, etc. And so, there will be times when you are looking at that and say, 'what I have to do here is basically make a decision on credibility', 
because that's all there is. [...] So, the area where discretion comes in is that judgement call (lonA30).

It is important to note that the statutory guidelines for social workers in relation to the safeguarding of children do not specifically mention families with NRPF (cf. Department for Education, 2015), nor does the law establish the exact or minimum amount of money to be paid in case support is granted. Since the latter always depends on the particular needs of the child in question it can vary significantly from one Borough to the next, as well as between cases (NRPF Network, 2011).

The amount that they pay is not set by law, but what often happens is that LAs have a policy somewhere. They probably don't publish it but somewhere they set some amounts; because quite often when you are speaking to social workers, they would say like [...] 'well, it's the set amount, we can't increase it' (lonA22).

What this NGO practitioner interpreted as an informal local policy might also be understood as individual professionals seeking to "deny that they have influence" in order to defend themselves "against the possibility that they might be able to act more as clients would wish" (Lipsky, 1980, p. 149). Interpreted as such, it is part of their trying to reconcile the two contradictory demands - immigration control and social protection - which underpin and severely trouble the application of Section 17 in the context of migrant irregularity.

At the same time, the difficulty of dealing with these contradictory demands has also triggered responses at the institutional level. As one of my interviewees indicated, many social service departments have changed their organisational structure in order to deal more effectively with irregular migrants' claims:

Certain social service departments now have NRPF-teams and so they seem to have... I mean, whereas I would dispute that that makes them better at judging whether the child is in need or not, they at least know a bit more about the immigration situation, and so they seem a little... they are less reluctant to get involved in it (lonA22).

As I will show in the following, this institutional adjustment clearly parallels what is also happening in UK hospitals and universities and thus appears to be quite emblematic for the British case while it does not seem to occur in Spain or at least Catalonia.

\subsection{3 'Managers' of Irregularity Within the Social Assistance System}

For Price and Spencer (2015), the existence of a dedicated NRPF-team constitutes one of three crucial factors that explain the significant variation in how different LAs respond to claims for support under Section 17 of the Children Act. ${ }^{11}$ Specifically tasked to deal with clients identified as having 'No Recourse to Public Funds', these

\footnotetext{
${ }^{11}$ The other two being the strength of local advocacy networks and the overall framing of the issue among LA staff.
} 
teams are particularly common within London, where the majority of families receiving Section-17-support live. ${ }^{12}$ From the perspective of LAs, having such a team seems to favour a more consistent application of the rules and more efficient internal referral procedures, but also allows for more effective gatekeeping, as the manager of an NRPF-team was keen to emphasise:

They will only be able to get support [...] through my team, the 'No Recourse Team', and then it's only provided conditional on various other things. So for example they have to be able to show that they are territorially the responsibility of [this Borough], that they are destitute, and that they have either an on-going application with the Home Office or are imminently about to make one [...] And that's the point about having the dedicated team, that when this function was spread across the LA's social care and health service, applicants could come in repeatedly, and they still do that, but what wasn't being picked up across so many people was patterns; information that was spread across a wide number of assessments that meant it was impossible to identify a scenario that had been heard before. When you have a small discrete team, you can [...] pick up patterns of information that are out in the community [about] what worked, and that other people would then come in repeating; we spot that much more quickly now (lonA30).

That NRPF-teams tend to perceive their role primarily in terms of gatekeeping rather than safeguarding and providing social care to vulnerable residents reflects the conditions under which they are being introduced. In one Borough, the annual costs of supporting a total of 278 NRPF-cases reached more than 6 million pounds by 2014 (compared to around $£ 150,000$ in the years before 2008). A review of how the Council had been dealing with such cases found the overall approach to be ambiguous and ineffective. Part of the identified problem was that "the assessment by social workers prioritises safeguarding [...] not NRPF eligibility criteria", as stated in the official minutes of a meeting where the review results were discussed in November 2014. In order to address this deficit a dedicated team of five specialised case workers and one 'embedded' Home Office worker was set up ${ }^{13}$ in order to deal with all NRPF-cases, about $80 \%$ of which concern migrant families in irregular situations. In a background paper presented at the same meeting, this "robust front door approach" was praised for having already "started to have significant impact on managing spend in this area". Whereas prior to the new approach more than half of all cases had been accepted for support, only one of the 96 applications that were made since then has been successful while eight were being supported temporarily pending full assessment. Based on the average acceptance rates of 9.7 (prior to the pilot) and 1.3 cases per month (during the pilot), another internal document calculates the annual saving for the LA at 2.2 million pounds.

Quite clearly, shifting the responsibility for carrying out initial case assessments from 'normal' social workers to NRPF-teams (who in this case are directly supported by a Home Office worker) has altered the priority driving the assessment itself. As an NGO practitioner put it,

\footnotetext{
${ }^{12}$ According to a countrywide survey, around $60 \%$ of families that received support during financial year 2012/13 were registered in one of the 33 London Boroughs, at least 16 of which already had established $N R P F$-teams (Price \& Spencer, 2015, p. 25).

${ }^{13}$ In June 2014, initially as a 6-months pilot scheme, after which it became a permanent arrangement.
} 
there can be a bit of a culture of looking at the immigration status first, or looking at the adults, and I think because it's not part of social services you don't get such child-centred approach. So, they are not really looking at 'is this child in need and what are the needs of this child'; they are looking at 'well this adult overstayed their visa', or 'this adult is somehow to blame' and you know, trying to allocate blame or deciding who deserves is not the correct test (lonA04).

Also Price and Spencer's (2015, p. 47) study suggests that those NRPF-teams that consist mainly of caseworkers rather than social workers "tended to conceive of their duties to these families as administrative tasks". According to the job description of an open position announced by another London Council in spring 2017, the ideal candidate to "manage the Council's NRPF-team" should have a degree or qualification in social work, even though the listed 'duties and responsibilities' comprised mostly administrative and managerial tasks. One of them was "to ensure that proactive liaison with the Home Office is taking place in relation to immigration status and that cases are progressed and moved on wherever possible". This also shows that one crucial function of NRPF-teams precisely consists in linking local social service departments even closer to the Home Office. In the eyes of a 'normal' social worker I interviewed (together with the NRPF-team manager), this again appears to be a mutual approximation:

I do think that there has been over the last few months a change from the Home Office as well, and I don't know whether or not that's the work that the No Recourse Team has been doing, because they are much more open to us. We had a visit, $[\ldots]$ they are coming and doing some training for us and we have a point of contact if we have concerns over any person, which actually is something that's practically unheard of. [...] They didn't have an open-door-approach at all. And I think that has changed because they have seen the value of actually working much more in partnership; and we hope to build on that as well (lonA30).

Another benefit of having a specially trained team dealing with all these cases centrally is that 'normal' social workers are thereby effectively 'buffered' from having to apply the logic of immigration control, as the same interviewee also indicated:

...if we see people where we think there is some issue around their status, then actually we refer it to [the NRPF-team] for them to investigate; that's where the expertise around migration is [...]. We don't have to make those judgements (lonA30).

Overall, it is no surprise that more and more social service departments in London either rely on dedicated Home Office caseworkers 'embedded' within their NRPF-teams or decide to join NRPF-Connect. Importantly, both kinds of institutional change are not just about expertise but also imply access to certain information that social services - as well as the Home Office - would otherwise lack. According to the NRPF-team manager, the difference between the two options is that

having an embedded worker is much more effective; because the embedded worker goes straight onto the system and is able to do a forensic analysis of what's happening. So, when we have walk-ins, we get the answer that minute: this person has a claim, this person doesn't have a claim, they have a long history, it has been refused so many times, or they have an outstanding appeal, or whatever. [...] And likewise, the reason the Home Office agreed to this, and the reason they are now extending these options to other Boroughs, is because they have learned that actually the quality of intelligence that they get form us, 
about patterns more than to do with individuals, is much greater than you will get from just the kind of exchange around individual cases [through NRPF-Connect] (lonA30).

While this again reflects shared interests between the LA and the Home Office, for applicants who are destitute and 'irregular' it means an almost total overlap of both parts of the administration: the one that might be legally obliged to help them and the one that threatens to deport them. The way in which the above-cited migrant mother spoke about an appointment with social services exemplifies this:

I have to call and ask my lawyer now, because they said that... they normally would invite immigration so that immigration will threaten people... that they will take them back home... so now I have to call my lawyer to let her know...

[Interviewer] So on Monday you are going to meet with your social worker, and you think there will also be an immigration officer?

Yes, immigration officers, that's what they do. That's what they do to threaten... they will say that it's better for them to take you back to your country than just to leave you here without support. [...] But once I have sent the application and I have the copy of the proof of posting, that way they can't... (lonB11).

Her reluctance to even meet her social worker without prior advice from a lawyer says a lot about the level of trust she has in the former. What triggers such reluctance is precisely the intimate institutional relationship between social work and immigration enforcement, to which the invention of NRPF-teams has significantly contributed.

\subsection{Social Assistance Workers as Migration Managers?}

In this chapter I have shown that under certain conditions the interests of social service providers and immigration officers can overlap to quite a significant extent. In the case of London, where this overlap is much more institutionalised, the common interest of both institutions in 'resolving' their caseload thereby tends to be geared towards return or deportation rather than regularisation, as one social worker suggested:

Working with the Home Office [is not] that easy, because it's kind of like... you think you are going into a room and say 'well I've got 157 families with Art. 8 applications, British children, etc.' - this is the stuff that we deal with, you know - 'so why don't you just pull out your caseworkers, grant them status because you will never remove them and they [...] kind of meet the conditions... and thus help me reduce my number of cases...?' But if I do any work with the Home Office it always has to be around family removals, you know, that's their interest (lonA15).

My analysis of the situation in Barcelona points in the opposite direction: The strict institutional separation between local social services and the immigration regime does represent a certain contradiction, but it allows the former to work with their clients, even if the latter renders them irregular. Individual social workers' engagement with migrants in irregular situations thereby automatically becomes geared towards the client's regularisation, as one social worker indicated: 


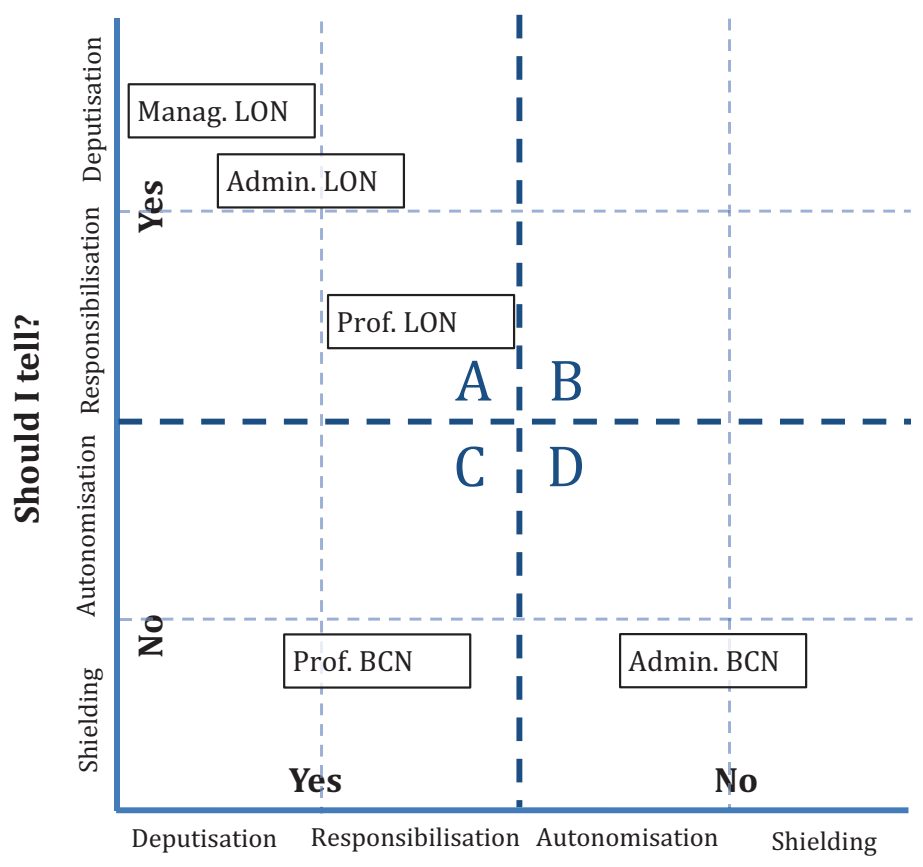

Should I know?

Fig. 7.1 The positions of different categories of social assistance workers in relation to migrant irregularity and its control

There are public administrations that are responsible for kicking you out and there are others, like social services and municipalities in general, who are in charge of helping you. It's a bit contradictory $[\ldots]$ but people eventually know it. [...] It's something that spreads through word of mouth, so people know us and know that they can come here with total peace of mind; and we're not going to pick on their administrative situation, but rather the opposite: we are going to orient them in how to solve this problem (bcnA22).

The welfare workers I met in Barcelona generally seemed to see the solution to the problem of irregularity in regularisation rather than return or even deportation, which arguably reflects the way in which migrant irregularity is generally framed and institutionalised in Spain, compared to Britain. Like in the previous two chapters, Fig. 7.1 summarises the empirical findings regarding the crucial question of whether or not the individuals working in the field of social assistance are obliged or encouraged to check their clients' immigration status and to share such knowledge with immigration authorities. As before, I do this by positioning the three rolecategories - administrators, professionals and managers of irregularity - within the analytical framework introduced in Sect. 2.4. The different positions within each sector reflect variations in terms of how explicit or compelling the underlying rules or expectations are in everyday practice, according to the reported perceptions and experiences of my interviewees. 
The diametrically opposed positions that administrators of social assistance and protection occupy in this framework (sector 'A' in the case of London; ' $D$ ' in the case of Barcelona) reflect the very different implications that a lack of immigration status has for local residents' general eligibility for these services. In London, access to publicly financed support provided by local social services is generally contingent on legal residence rights and thus almost automatically involves an immigration check at the point of first contact. In the exceptional case of a suspected human rights breach or immediate child protection concern social services will provide the necessary support but are also obliged to notify immigration authorities. In Barcelona, reception staff is required to ascertain applicants' identity and local residence, but not necessarily their immigration status (although they sometimes do). It is then on the social worker to determine how far support can go in any particular case.

The job of professional providers of social services always involves a significant element of control over the client and his or her actions and behaviour. Arguably more than professionals working in education, and healthcare in particular, social workers are generally expected to not only sanction certain wrongdoings, but potentially also to trigger law-enforcement if they discover (serious) breaches of the law. In both environments this is mostly in relation to the safeguarding of others and does not usually involve immigration control as such. However, the level of engagement and the exact measures through which they can provide support often depend on immigration status, so that they will at a certain point be required to know a client's ir/regularity. In London this is the case from the very beginning, but it is usually not the social worker him/herself who would pass such information on to the Home Office (even though there are clear incentives for doing so). Social workers in Barcelona, in contrast, have to determine immigration status only in relation to more formalised and/or longer-term assistance and have no duty or incentive (nor a specific interest) to inform immigration authorities.

Like in the sphere of education, specific managers of irregularity only exist in the case of London, and here in the form of the so-called NRPF-teams, which institutionalise the exact opposite of a firewall between local social service departments and the national immigration enforcement agency. Even though they are institutionally integrated in the former, they at least partly fulfil the function of the latter. An important part of this function is not only to establish the immigration status of 'suspicious' clients and assess the likelihood of them being either regularised or deported, but also to share this knowledge with the Home Office. Like 'Overseas Visitors Managers' in NHS hospitals and Immigration Departments of public universities, they thereby act as an extension of the Home Office into the various spheres of local service provision, which in this case is even underpinned by a more explicit legal obligation.

The UK governments' 'hostile environment' approach and rhetoric, in combination with increasing financial pressure, thereby significantly affects how migrant irregularity is perceived and dealt with at the local level. This becomes particularly apparent in the domain of social assistance, as a LA representative emphasised: 
It [used to be] very much 'LAs versus Home Office' on what should happen with this client group, and LAs were very much like 'well if there is a child in need, we must act'. And so, it's just like a warning thing for me at the moment [...] that in fact you are now struggling to maintain a kind of consensus amongst the LAs on how they perceive the client group. And if they undermine the client group by calling them fraudsters or... you know, talking mainly about the criminality of their situation, which is a discussion that seems to be coming out from all sides at the moment, you kind of undermine [LAs'] ability to [...] stave off some of the more hostile immigration policies (lonA15).

Instead of resisting central government policies that undermine their ability to serve the communities they are responsible for, many local social service departments in London are developing strategies that allow them to evade those already very limited statutory responsibilities that they might still have towards destitute local residents in irregular situations. Even more than health centres and hospitals, and certainly more than schools, these local institutions are thus becoming part and parcel of the 'hostile environment' that the government seeks to create for this category of people. In the worst case, this means that legislation like the UK Children Act only effectively protects the human rights of those children in irregular situations whose parents' immigration claim, i.e., their prospects for regularisation, are strong enough to ensure that they will not be deported as a result of trying to activate these rights. For one of the social workers I interviewed in London, LAs are thereby deliberately given a task on which they are bound to fail:

Ultimately it is the LA that will do the assessment about whether something is a breach of human rights or not. And that is something that was never ever meant to be our role, and it's not something we are resourced to do. We just had to become experts at it, because we have been handed that responsibility, which is a responsibility that really should lie on central government. And because they have been failing on it, they simply wanted to transfer the arena of failure from themselves to the LAs. And then, somewhere down the line, it will be 'look, how awful LAs are', because they are failing on them (lonA30).

\section{References}

Ajuntament de Barcelona. (2005). Barcelona Inclusiva 2005/2010: Pla Municipal per a la Inclusió Social. Barcelona.

Alesina, A., \& Glaeser, E. (2004). Fighting poverty in the US and Europe. Oxford University Press. https://doi.org/10.1093/0199267669.001.0001

Artiles, A. M., \& Meardi, G. (2014). Public opinion immigration and welfare in the context of uncertainty. Transfer: European Review of Labour and Research, 20(1), 53-68. https://doi. org/10.1177/1024258913515368

Banting, K. G. (2000). Looking in three directions. Migration and the European welfare state in comparative perspective. In M. Bommes \& A. Geddes (Eds.), Immigration and welfare: Challanging the borders of the welfare state (pp. 13-33). Routledge.

Borjas, G. J. (1999). Immigration and welfare magnets. Journal of Labor Economics, 17(4), 607-637. Available at: http://www.jstor.org/stable/10.1086/209933

Burgoon, B. (2014). Immigration, integration, and support for redistribution in Europe. World Politics. Cambridge University Press, 66(03), 365-405. https://doi.org/10.1017/ S0043887114000100 
Butler, P. (2016). Poorer renters at risk from homelessness as benefit shortfall grows. The Guardian. Available at: https://www.theguardian.com/society/2016/aug/24/poor-uk-privaterent-homelessness-risk-housing-benefit-shortfall-2020. Accessed 28 Jan 2017.

Chauvin, S., \& Garcés-Mascareñas, B. (2020). Contradictions in the moral economy of migrant irregularity. In S. Spencer \& A. Triandafyllidou (Eds.), Migrants with irregular status in Europe (pp. 33-49). Springer. https://doi.org/10.1007/978-3-030-34324-8_3

CORAM. (2013). Growing up in a hostile environment: The rights of undocumented migrant children in the UK.

Crawley, H., Hemmings, J., \& Price, N. (2011). Coping with destitution. Survival and livelihood strategies of refused asylum seekers living in the UK. Available at: https://oxfamilibrary.openrepository.com/bitstream/handle/10546/121667/rr-coping-with-destitution-survival-strategiesuk-040211-en.pdf;jsessionid=B1F8327BEB8B707EC2BA7D3A558CF595? sequence $=1$. Accessed 11 Jan 2017.

Cuadra, C. B., \& Staaf, A. (2014). Public social services' encounters with irregular migrants in Sweden: Amid values of social work and control of migration. European Journal of Social Work. Routledge, 17(1), 88-103. https://doi.org/10.1080/13691457.2012.739556

Department for Communities and Local Government. (2016). Controlling migration fund: Mitigating the impacts of immigration on local communities - Prospectus. London.

Department for Education. (2015). Working together to safeguard children. A guide to interagency working to safeguard and promote the welfare of children (p. 393). https://doi. org/10.1080/13561820020003919

Esping-Andersen, G. (1990). The three worlds of welfare capitalism. Princeton University Press.

Furman, R., et al. (2012). The criminalization of immigration: Value conflicts for the social work profession. Journal of Sociology and Social Welfare, 39(1), 169-185.

Gaston, N. (2015). International migration, immigration policy and welfare spending. International Migration, 53(2), 386-396. https://doi.org/10.1111/imig.12181

Gomà, R. (2006). Diversidad y políticas sociales en Barcelona. In G. Pinyol (Ed.), Inmigración y derechos de ciudadanía. III Seminario Inmigración y Europa (pp. 112-118). Fundación CIDOB. Available at: http://www.cidob.org/es/media2/publicacions/monografias/ iii_seminari_migracions/09_goma_cast

Guiraudon, V. (2000). The Marshallian triptych reordered: The role of courts and bureaucracies in furthering migrants' social rights. In M. Bommes \& A. Geddes (Eds.), Immigration and welfare: Challenging the borders of the welfare state (pp. 72-89). Routledge.

Hastings, A., et al. (2013). Coping with the cuts? Local government and poorer communities. Glasgow. Available at: https://www.jrf.org.uk/sites/default/files/jrf/migrated/files/localgovernment-communities-full.pdf. Accessed 31 Jan 2017.

Hemerijck, A. C., et al. (2013). Changing European welfare states and the evolution of migrant incorporation regimes: Background paper reviewing welfare state structures and reform dynamics in a comparative. Available at: http://www.compas.ox.ac.uk/media/PR-2013IMPACIM_Background_Welfare_States.pdf. Accessed 16 Jan 2017.

Home Office (2016). Reforming support for migrants without immigration status. The new system contained in Schedules 8 and 9 to the Immigration Bill. Accessible online: https://assets. publishing.service.gov.uk/government/uploads/system/uploads/attachment_data/file/494240/ Support.pdf

Lipsky, M. (1980). Street-level bureaucracy: The dilemmas of the individual in public service. Russell Sage Foundation.

Manzanedo, C., \& Fabre, R. G. (2009). Impacto de la crisis económica sobre los inmigrantes irregulares en España. Available at: http://pueblosunidos.org/wp-content/uploads/2009Impact oCrisisEmigrantesEspaña.pdf. Accessed 13 Jan 2017.

Marshall, T. H. (1950). Citizenship and social class, and other essays. Cambridge: Cambridge University Press.

Moreno, F. J. (2007). Inmigración y Estado de Bienestar en España. Política y Sociedad, 44(2), 171-184. https://doi.org/10.5209/POSO.23431 
Moreno, F. J., \& Bruquetas, M. (2011). Inmigración y Estado de bienestar en España, Colección Estudios Sociales. Barcelona.

Morris, L. (2002). Managing migration: Civic stratification and migrants' rights. Routledge.

NRPF Network. (2011). Practice guidance for local authorities: Assessing and supporting children \& families and former looked-after children who have No Recourse to Public Funds (NRPF) for support from local authorities under the Children Act 1989. London (Islington).

NRPF Network. (2015). Practice guidance for local authorities (England): Assessing and supporting adults who have no recourse to public funds.

Papadopoulos, D., Stephenson, N., \& Tsianos, V. (2008). Escape routes: Control and subversion in the twenty-first century. Pluto Press.

PICUM. (2015). Undocumented migrants and the Europe 2020 strategy: Making social inclusion a reality for all migrants in Europe. Brussels.

Price, J., \& Spencer, S. (2014). City-level responses to migrant families with restricted access to welfare benefits. Oxford. Available at: https:/www.compas.ox.ac.uk/fileadmin/files/ Publications/Reports/Report_City_level_responses.pdf

Price, J., \& Spencer, S. (2015). Safeguarding children from destitution: Local authority responses to families with 'no recourse to public funds'. Oxford. Available at: www.compas.ox.ac.uk/ research/welfare/nrpf/

Refugee Council. (2012). Between a rock and a hard place: The dilemma facing refused asylum seekers.

Rodríguez-Cabrero, G. (2011). The consolidation of the Spanish welfare state (1975-2010). In A. M. Guillén \& M. León (Eds.), The Spanish welfare state in European context (pp. 17-38). Ashgate.

Rodríguez-Cabrero, G., et al. (2015). ESPN thematic report on social investment: Spain. Brussels.

Ruhs, M. (2008). Economic research and labour immigration policy. Oxford Review of Economic Policy, 24(3), 403-426. https://doi.org/10.1093/oxrep/grn034

Ruhs, M., \& Martin, P. (2008). Numbers vs. rights: Trade-offs and guest worker programs. International Migration Review, 42(1), 249-265. https://doi.org/10.1111/j.1747-7379.2007.00120.x

Sainsbury, D. (2012). Welfare states and immigrant rights: The politics of inclusion and exclusion. Oxford University Press. https://doi.org/10.1093/acprof:oso/9780199654772.003.0002

Schweitzer, R. (2020). How inclusive institutions enforce exclusive immigration rules: Mainstream public service provision and the implementation of a hostile environment for irregular migrants living in Britain. In S. Hinger \& R. Schweitzer (Eds.), Politics of (dis)integration (pp. 121-140). Springer. https://doi.org/10.1007/978-3-030-25089-8_7

Soysal, Y. N. (1994). Limits of citizenship. Migrants and postnational membership in Europe. University of Chicago Press.

Stephens, M., et al. (2010). Study on housing exclusion: Welfare policies, labour market and housing provision. Brussels. Available at: https://pureapps2.hw.ac.uk/portal/files/4727289/housing_exclusion_1_.pdf

van der Leun, J. (2003). Looking for loopholes. Amsterdam University Press. https://doi. org/10.2307/j.ctt46n2vd

Van Der Leun, J. (2006). Excluding illegal migrants in The Netherlands: Between national policies and local implementation. West European Politics, 29(2), 310-326. https://doi. org/10.1080/01402380500512650

Vine, J. (2010). Local immigration teams: The change management process. Available at: http:// icinspector.independent.gov.uk/wp-content/uploads/2010/03/Local-Immigration-Teams_TheChange-Management-Process.pdf

Vrăbiescu, I. (2017). Roma migrant children in Catalonia: Between the politics of benevolence and the normalization of violence. Ethnic and Racial Studies, 40(10), 1663-1680. 
Open Access This chapter is licensed under the terms of the Creative Commons Attribution 4.0 International License (http://creativecommons.org/licenses/by/4.0/), which permits use, sharing, adaptation, distribution and reproduction in any medium or format, as long as you give appropriate credit to the original author(s) and the source, provide a link to the Creative Commons license and indicate if changes were made.

The images or other third party material in this chapter are included in the chapter's Creative Commons license, unless indicated otherwise in a credit line to the material. If material is not included in the chapter's Creative Commons license and your intended use is not permitted by statutory regulation or exceeds the permitted use, you will need to obtain permission directly from the copyright holder. 